\title{
Biomphalaria glabrata transcriptome: cDNA microarray profiling identifies resistant- and susceptible-specific gene expression in haemocytes from snail strains exposed to Schistosoma mansoni
}

\author{
Anne E Lockyer ${ }^{1}$, Jenny Spinks ${ }^{1}$, Richard A Kane ${ }^{1}$, Karl F Hoffmann ${ }^{2,4}$, \\ Jennifer M Fitzpatrick ${ }^{2,5}$, David Rollinson ${ }^{1}$, Leslie R Noble ${ }^{3}$ and \\ Catherine S Jones*3
}

\begin{abstract}
Address: ${ }^{1}$ Wolfson Wellcome Biomedical Laboratories, Department of Zoology, The Natural History Museum, London, SW7 5BD, UK 2Department of Pathology, Cambridge University, Tennis Court Road, Cambridge, UK, ${ }^{3}$ Institute of Biological and Environmental Sciences, School of Biological Sciences, Zoology Building, Tillydrone Avenue, University of Aberdeen, Aberdeen, AB24 2TZ, UK, ${ }^{4}$ Institute of Biological Sciences, Edward Llwyd Building, University of Wales, Aberystwyth, Ceredigion, SY23 3DA, UK and ${ }^{5}$ Department of Medicine, University of Southampton, Bassett Crescent East, Southampton, Hampshire SO16 7PX, UK

Email: Anne E Lockyer - a.lockyer@nhm.ac.uk; Jenny Spinks - jennyspinks@netscape.net; Richard A Kane - r.kane@nhm.ac.uk; Karl F Hoffmann - krh@aber.ac.uk; Jennifer M Fitzpatrick - jf106@soton.ac.uk; David Rollinson - dr@nhm.ac.uk;

Leslie R Noble - l.r.noble@abdn.ac.uk; Catherine S Jones* - c.s.jones@abdn.ac.uk

* Corresponding author
\end{abstract}

Published: 29 December 2008

BMC Genomics 2008, 9:634 doi:10.1 I86/147I-2164-9-634

This article is available from: http://www.biomedcentral.com/I47I-2/64/9/634

(C) 2008 Lockyer et al; licensee BioMed Central Ltd.

This is an Open Access article distributed under the terms of the Creative Commons Attribution License (http://creativecommons.org/licenses/by/2.0), which permits unrestricted use, distribution, and reproduction in any medium, provided the original work is properly cited.

\begin{abstract}
Background: Biomphalaria glabrata is an intermediate snail host for Schistosoma mansoni, one of the important schistosomes infecting man. B. glabrata/S. mansoni provides a useful model system for investigating the intimate interactions between host and parasite. Examining differential gene expression between S. mansoni-exposed schistosome-resistant and susceptible snail lines will identify genes and pathways that may be involved in snail defences.
\end{abstract}

Results: We have developed a 2053 element cDNA microarray for B. glabrata containing clones from ORESTES (Open Reading frame ESTs) libraries, suppression subtractive hybridization (SSH) libraries and clones identified in previous expression studies. Snail haemocyte RNA, extracted from parasite-challenged resistant and susceptible snails, 2 to $24 \mathrm{~h}$ post-exposure to $S$. mansoni, was hybridized to the custom made cDNA microarray and 98 differentially expressed genes or gene clusters were identified, 94 resistant-associated and 4 susceptible-associated. Quantitative PCR analysis verified the cDNA microarray results for representative transcripts. Differentially expressed genes were annotated and clustered using gene ontology (GO) terminology and Kyoto Encyclopaedia of Genes and Genomes (KEGG) pathway analysis. 61\% of the identified differentially expressed genes have no known function including the 4 susceptible strain-specific transcripts. Resistant strain-specific expression of genes implicated in innate immunity of invertebrates was identified, including hydrolytic enzymes such as cathepsin L, a cysteine proteinase involved in lysis of phagocytosed particles; metabolic enzymes such as ornithine decarboxylase, the rate-limiting enzyme in the production of polyamines, important in inflammation and infection processes, as well as scavenging damaging free radicals produced during production of reactive oxygen species; stress response genes such as HSP70; proteins involved in signalling, such as importin 7 and copine I, 
cytoplasmic intermediate filament (IF) protein and transcription enzymes such as elongation factor $\mathrm{I} \alpha$ and EF-2.

Conclusion: Production of the first cDNA microarray for profiling gene expression in B. glabrata provides a foundation for expanding our understanding of pathways and genes involved in the snail internal defence system (IDS). We demonstrate resistant strain-specific expression of genes potentially associated with the snail IDS, ranging from signalling and inflammation responses through to lysis of proteinacous products (encapsulated sporocysts or phagocytosed parasite components) and processing/degradation of these targeted products by ubiquitination.

\section{Background}

Schistosomiasis, the most widespread trematode infection, is estimated to infect around 200 million people in 75 countries of the developing world, leading to chronic debilitating disease and up to 200000 deaths per year [1]. The freshwater snail Biomphalaria glabrata is an intermediate host for Schistosoma mansoni, a digenean parasite that causes human intestinal schistosomiasis. This medically relevant gastropod is a member of one of the largest invertebrate phyla, the Mollusca, which are lophotrochozoans, a lineage of animal evolution distinct from ecdysoans, represented by present model invertebrates such as Caenorhabditis and Drosophila. Many of the genomic studies in molluscs have focussed on bivalves owing to the importance of these organisms in aquaculture and fisheries and to their role in marine environmental science $[2,3]$, while in gastropods, expressed sequence tag (EST) studies have been carried out in Lymnaea stagnalis [4] and B. glabrata [5-7]. Characterizing genes and biochemical pathways central to immunity and defence in gastropods is predicted to reveal innovative data, significant due to the medical and economic importance of intermediate host snails in parasite transmission, and B. glabrata is poised to become the next invertebrate model organism. Indeed, advances towards the ultimate goal of obtaining the B. glabrata genome sequence [8] include the complete mitochondrial genome [9], the development of a BAC library for genome sequencing [10] and complementary gene discovery projects [5-7]. Interactions between snails and schistosomes are complex and there exists an urgent need to elucidate pathways involved in snail-parasite relationships as well as to identify those factors involved in the intricate balance between the snail internal defence system (IDS) and trematode infectivity mechanisms that determine the success or failure of an infection [for a review see [11]].

Molluscs appear to lack an adaptive immune system like that found in vertebrates and, instead, are considered to use various innate mechanisms involving cell-mediated and humoral reactions (non-cellular factors in plasma/ serum or haemolymph) that interact to recognize and eliminate invading pathogens or parasites in incompatible or resistant snails [for reviews see [12-14]]. However, a diverse family of fibrinogen related proteins (FREPs) containing immunoglobulin-like domains has been discovered in B. glabrata and may play a role in snail defence [15]. Circulating haemocytes (macrophage-like defence cells) in the snail haemolymph are known to aggregate in response to trauma, phagocytose small particles (bacteria, and fungi) and encapsulate larger ones, such as parasites. Final killing is effected by haemocyte-mediated cytotoxicity mechanisms involving non-oxidative and oxidative pathways, including lysosomal enzymes and reactive oxygen/nitrogen intermediates [16,17]. Certain alleles of cytosolic copper/zinc superoxide dismutase (SOD1) have been associated with resistance $[18,19]$ also suggesting these processes are important in the snail IDS.

Compatible snail-trematode infections may reflect the parasite's capacity to avoid or interfere with the innate response of the snail. The term 'resistant' can be applied to those individuals within a single snail species that are able to evade infection by a species or strain of schistosome that is normally capable of parasitizing that species of snail. Identification of specific molecules mediating the defensive events in snail intermediate hosts, in particular those differentially expressed in resistant/incompatible snails, is expected to reveal much about the pathways and processes involved. Previous studies of differential gene expression in resistant and susceptible snail lines have used a number of different techniques including differential display [20-25] and suppression subtractive hybridization (SSH) [26,27] to identify in each case, some differentially expressed genes. The application of cDNA microarray technology allows large-scale analysis of differential gene expression, using large numbers of sequenced cDNA clones, which will enable a more detailed examination of the B. glabrata transcriptome. This paper describes the construction of the first B. glabrata microarray using previously sequenced ORESTES clones [6] as well as new sequences from SSH libraries enriched for differentially expressed genes, and demonstrates its use in detecting differentially expressed transcripts in the haemocytes of parasite-challenged resistant and susceptible snail lines, with the aim of identifying strain-specific transcripts potentially involved in snail internal defence. 


\section{Results \\ Sequence analysis of SSH and ORESTES clones for microarray fabrication}

To initiate large scale analysis of differential gene expression in B. glabrata, a cDNA microarray was constructed from 1062 previously sequenced PCR-amplified ORESTES clones [6] and, in addition to these, 980 new sequenced clones from existing SSH libraries [27]. It also contains transcripts derived from our previous expression studies [20-22]. The ORESTES clones were from the first $27 \mathrm{Bg}$ ORESTES libraries [6], available at the time of printing and were derived from 4 different tissues (ovotestis, headfoot, haemopoietic organ and haemocytes), from the two snail strains used in this experiment, NHM3017 (resistant) and NHM1742 (susceptible). All the available EST clones were printed, including those from tissues other than haemocytes, since it could not be ascertained $a$ priori that none of these would be involved in snail defence, or that transcripts originally derived from tissues other than haemocytes would definitely not be expressed in the haemocytes. The analyzed ESTs were screened to remove duplicates within each library. In addition to the clones derived from the ORESTES libraries, 8 haemocyte and haemopoietic organ (the organ responsible for producing the haemocytes) SSH libraries (described in [27]) were available for sequencing and clone selection. Two to three 96 well plates of clones were sequenced from each library. A total of 1728 sequences were obtained (Table $1)$, of which just over $2 \%(n=40)$ had been previously sequenced from B. glabrata. Over $35 \%$ had no known identity $(n=606)$, either having no match in publicly available sequence databases, or matching a protein or other EST that had no known identity. After removal of duplicate, short (<80 bp) and ribosomal sequences, 980 were available for printing on the microarray.
The available ESTs from SSH and ORESTES $(n=2042)$ were compared to GenBank and where possible gene ontology was assigned. The assignments in all three categories, molecular function, biological process and cellular component show no obvious differences in the sequence types obtained from the two different methods (Fig. 1). An analysis of metabolic pathways using the Kyoto Encyclopaedia of Genes and Genomes (KEGG; see Additional file 1) showed that, generally, genes from similar pathways were identified from both ORESTES and SSH, for instance, genes implicated in the immune system showed similar numbers in each pathway from both techniques. However, there were many more genes involved in oxidative phosphorylation sequenced from SSH (76 clones, representing 27 different enzymes) when compared to ORESTES ( 6 clones, representing 6 different enzymes) and the same was seen with the numbers of ribosomal proteins from SSH (37 clones, representing 32 different enzymes) compared to ORESTES (7 clones, representing 7 different enzymes).

\section{Expression profiling by microarray analysis}

The microarray was used for a direct comparison of mRNA from haemocytes of parasite-exposed resistant and susceptible snails. Haemocytes sampled over the first $24 \mathrm{~h}$ post parasite exposure were compared to investigate differences between snail lines after parasite exposure during the period when the haemocytes are thought to respond and encapsulate the parasite in resistant snails [28]. This approach was designed to identify large and significant differences in gene expression between the two snail lines, although small, transient RNA expression changes might not be identified. Since very small amounts of RNA were available from the haemocytes, independent SMART amplifications [29] and labelling reactions were carried out and four technical replicate hybridizations performed.

Table I: Blast results summary.

\begin{tabular}{|c|c|c|c|c|}
\hline \multirow[b]{2}{*}{ Category } & \multicolumn{2}{|c|}{ All sequences } & \multicolumn{2}{|c|}{ Non-redundant sequences } \\
\hline & $\mathrm{N}^{\circ}$ sequences & $\%$ sequences & $\mathrm{N}^{\circ}$ sequences & $\%$ sequences \\
\hline Protein & 281 & 16.26 & 275 & 28.06 \\
\hline Mitochondrial protein & 91 & 5.27 & 63 & 6.43 \\
\hline Ribosomal protein & 37 & 2.14 & 36 & 3.67 \\
\hline Biomphalaria protein & 10 & 0.58 & 7 & 0.71 \\
\hline Biomphalaria fragment & 30 & 1.74 & 20 & 2.04 \\
\hline Ribosomal & 315 & 18.23 & 2 & 0.20 \\
\hline Unknown (no BLAST match) & 525 & 30.38 & 497 & 50.71 \\
\hline Unknown EST & 46 & 2.66 & 40 & 4.08 \\
\hline Unknown protein & 35 & 2.03 & 33 & 3.37 \\
\hline Other & 358 & 20.72 & 7 & 0.71 \\
\hline Total & 1728 & 100.00 & 980 & 100.00 \\
\hline
\end{tabular}

Analysis of the types of sequences obtained from the B. glabrata SSH libraries identified with Blast searches of GenBank. 

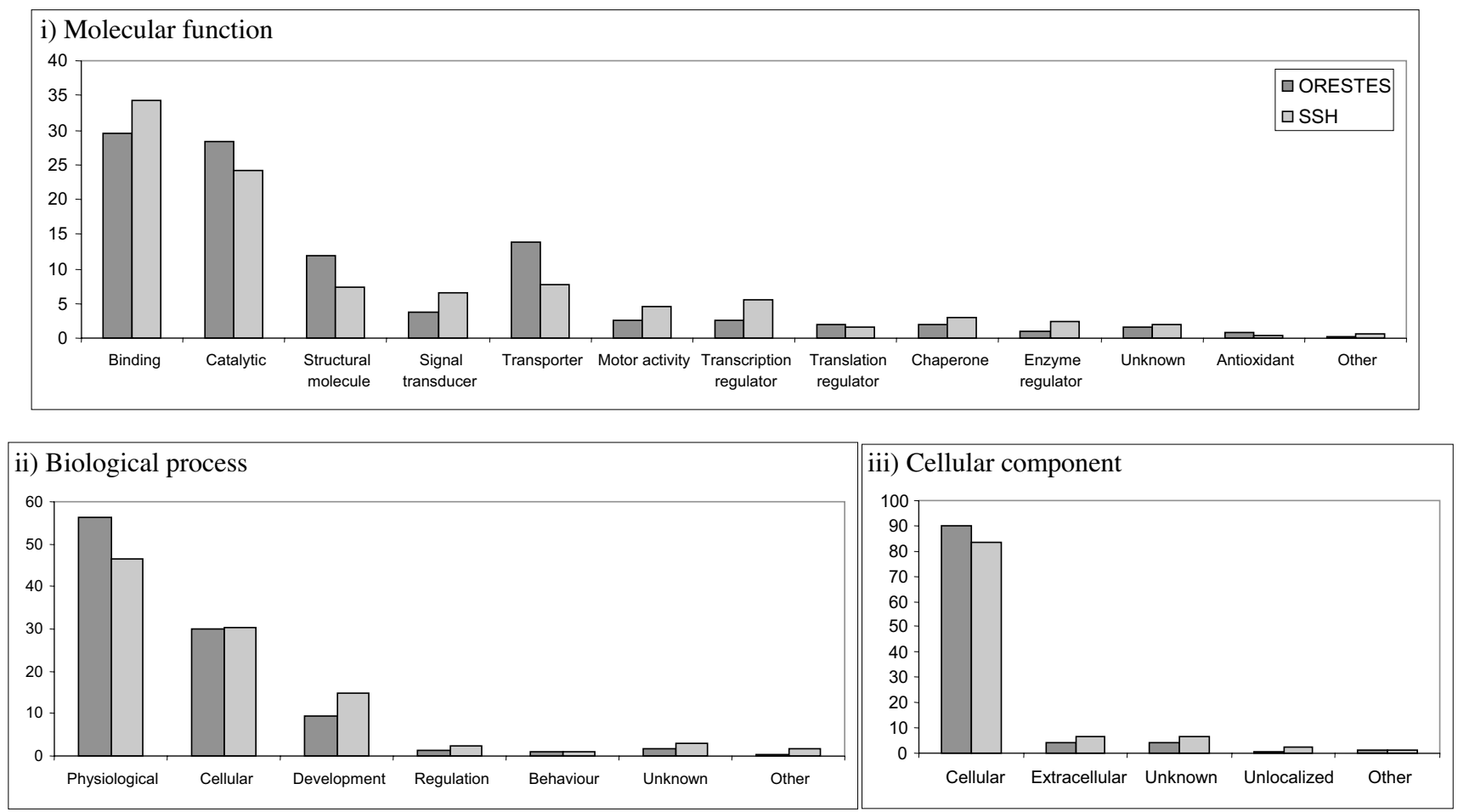

\section{Figure I}

Gene Ontology assignments to compare the percentage of clones from ORESTES and SSH in each category for i) molecular function; ii) biological process and iii) cellular component.

SMART amplification has been shown to have a higher true-positive rate than global amplification, but has a lower absolute discovery rate, and a systematic compression of observed expression ratio [30].

Analysis of duplicate spots on each array showed good correlation of normalized mean pixel intensity ratios (correlation coefficients 0.9577-0.9889) demonstrating that the hybridizations were consistent within each array (results not shown). The data were screened to remove weak signals below the level of background hybridization in both channels based on negative control vector levels of hybridization. Comparisons were made between technical replicate arrays, of mean (from duplicate features) normalized mean pixel intensity ratios obtained for each clone, using the data that passed the filtering and background (vector) threshold (see Additional file 2). Correlation coefficients for each array comparison were high, ranging from 0.8452 to 0.9604 , showing good agreement in gene expression values between array hybridizations, suggesting that SMART amplification of the CDNA was not affecting representation of transcripts. The amplified cDNA demonstrated a good degree of hybridization reproducibility and a low level of variation between tech- nical replicates, giving confidence to the assignment of differentially expressed strain-associated transcripts.

To identify genes showing differential expression between the resistant and susceptible snail haemocytes, 99\% confidence intervals were calculated based on the remaining data, but excluding data from SSH clones. These were not included in calculating significance intervals, since the 99\% confidence intervals are based on the assumption that the clones are normally distributed; however since the SSH clones were enriched for differential expression this assumption is not true for these clones. Clones that fell outside the $99 \%$ confidence interval in 3 or more of the 4 replicates were designated differentially expressed (Table 2). A total of 110 differentially expressed transcripts were identified, 105 were from the resistant haemocytes and only 5 were from the susceptible haemocytes. All of these identified genes showed an average (across the 4 replicates) of between 3 and 5.3 fold difference in expression between resistance and susceptible snails (Table 2). Nine candidates, 4 susceptible-associated transcripts and 5 resistant-associated transcripts, were selected for confirmation of differential expression with qPCR using unamplified cDNA (Fig. 2). In each case the 
Table 2: Differentially expressed genes.

\begin{tabular}{|c|c|c|c|c|c|c|}
\hline $\mathrm{dbEST}$ Ac No & Mean & Source ${ }^{a}$ & BlastX match ${ }^{b}$ & Organism & Acc No & Expect \\
\hline EW996975* & -5.261 & $\mathrm{SSH}$ & Ornithine decarboxylase I & Danio rerio & NP 571876.1 & $3 \mathrm{E}-16$ \\
\hline EW997424 & -5.124 & $\mathrm{SSH}$ & Unknown & & & \\
\hline EW997539 & -4.996 & $\mathrm{SSH}$ & Unknown & & & \\
\hline CK656700 & -4.845 & ORESTES & Multidrug resistance transporter-like protein & Pseudopleuronectes americanus & AALI5|48.1 & $2 \mathrm{E}-34$ \\
\hline CO870193* & -4.816 & ORESTES & Unknown & & & \\
\hline CKI49228* & -4.806 & ORESTES & Titin & Homo sapiens & CAA49245.I & $3 \mathrm{E}-17$ \\
\hline EW997032* & -4.801 & $\mathrm{SSH}$ & Unknown & & & \\
\hline CK656739 & -4.772 & ORESTES & Unknown ${ }^{2}$ & & & \\
\hline EW997027 & -4.698 & $\mathrm{SSH}$ & Unknown & & & \\
\hline EW997530 & -4.698 & SSH & Unknown & & & \\
\hline CK656724 & -4.696 & ORESTES & Unknown & & & \\
\hline EW997444 & -4.643 & $\mathrm{SSH}$ & MBCTLI & Monosiga brevicollis & AAP78680.1 & $5 \mathrm{E}-04$ \\
\hline CO87022I & -4.597 & ORESTES & Unknown' & & & \\
\hline CK656720* & -4.594 & ORESTES & Unknown & & & \\
\hline EW997542 & -4.544 & $\mathrm{SSH}$ & Unknown & & & \\
\hline CK656728 & -4.539 & ORESTES & Crooked neck-like I protein & Mus musculus & NP 080096.1 & IE- 105 \\
\hline EW997099 & -4.488 & $\mathrm{SSH}$ & Unknown 9 & & & \\
\hline EW996832 & -4.472 & SSH & $\mathrm{NADH}$ ubiquinone oxidoreductase & Caenorhabditiselegans & NP 496376.1 & $\mathrm{IE}-30$ \\
\hline EW997050 & -4.459 & $\mathrm{SSH}$ & Bystin & H. sapiens & AAH50645.I & $2 \mathrm{E}-34$ \\
\hline EW996838 & -4.417 & $\mathrm{SSH}$ & Unknown & & & \\
\hline EW99683I & -4.407 & $\mathrm{SSH}$ & Unknown & & & \\
\hline EW997370 & -4.382 & $\mathrm{SSH}$ & Unknown & & & \\
\hline CO870223 & -4.361 & ORESTES & Unknown' & & & \\
\hline EW997028 & -4.316 & SSH & Unknown & & & \\
\hline EW997II7 & -4.306 & SSH & Unknown & & & \\
\hline EW997432 & -4.303 & $\mathrm{SSH}$ & Unknown & & & \\
\hline CK656726 & -4.299 & ORESTES & Cytoplasmic intermediate filament protein & Ascaris lumbricoides & CAA60047.1 & $3 E-27$ \\
\hline EW997187 & -4.287 & $\mathrm{SSH}$ & Unknown & & & \\
\hline EW997456 & -4.264 & $\mathrm{SSH}$ & Unknown & & & \\
\hline EW996835 & -4.248 & $\mathrm{SSH}$ & Unknown & & & \\
\hline EW997566 & -4.247 & $\mathrm{SSH}$ & Unknown & & & \\
\hline CK65674I & -4.225 & ORESTES & Ubiquitin & Suberites domuncula & CAA76578.I & $9 \mathrm{E}-26$ \\
\hline EW996808 & -4.224 & $\mathrm{SSH}$ & NHL domain containing protein & C. elegans & NP 499028.1 & $4 \mathrm{E}-10$ \\
\hline EW996834 & -4.201 & $\mathrm{SSH}$ & Unknown & & & \\
\hline CO870200 & -4.195 & ORESTES & Unknown' & & & \\
\hline EW99745I & -4.193 & $\mathrm{SSH}$ & Unknown & & & \\
\hline EW997446 & -4.158 & $\mathrm{SSH}$ & Importin 7; RAN-binding protein 7 & D. rerio & NP 006382.1 & $9 \mathrm{E}-40$ \\
\hline EW997|44 & -4.122 & SSH & Unknown & & & \\
\hline EW9968I2 & -4.120 & $\mathrm{SSH}$ & Unknown & & & \\
\hline EW997049 & -4.109 & $\mathrm{SSH}$ & Unknown & & & \\
\hline EW997528 & -4.103 & $\mathrm{SSH}$ & Myosin light chain kinase smooth & Bos taurus & $\underline{Q} 28824$ & 7E-09 \\
\hline EW997428 & -4.094 & $\mathrm{SSH}$ & Hypothetical protein & Deinococcus radiodurans & NP 294693.1 & $2 \mathrm{E}-15$ \\
\hline EW997II8 & -4.068 & $\mathrm{SSH}$ & Unknown8 & & & \\
\hline CK656734 & -4.056 & ORESTES & Unknown' & & & \\
\hline CKI49216 & -4.053 & ORESTES & Unknown & & & \\
\hline EW997092 & -4.050 & SSH & Unknown8 & & & \\
\hline EW997556 & -4.035 & SSH & Unknown & & & \\
\hline EW99753I & -4.021 & $\mathrm{SSH}$ & Unknown & & & \\
\hline CK656703 & -3.992 & ORESTES & Sqstm I protein & M. musculus & AAH06019.1 & 0.0003 \\
\hline EW997407 & -3.976 & SSH & Unknown & & & \\
\hline EW997035 & $-3.97 \mid$ & $\mathrm{SSH}$ & Unknown & & & \\
\hline EW997077 & -3.961 & $\mathrm{SSH}$ & Unknown & & & \\
\hline CK656698 & -3.954 & ORESTES & Unknown & & & \\
\hline EW997078 & -3.932 & $\mathrm{SSH}$ & Unknown & & . & \\
\hline CK6567II & -3.932 & ORESTES & ADP/ATP carrier ${ }^{2}$ & Neocallimastix patriciarum & AAL79525.I & $\mathrm{IE}-30$ \\
\hline EW997555 & -3.920 & $\mathrm{SSH}$ & Elongation factor $-2^{7}$ & Rattus norvegicus & $\overline{\text { CAC81931.I }}$ & $3 E-32$ \\
\hline EW996976 & -3.915 & $\mathrm{SSH}$ & Ornithine decarboxylase & C. elegans & NP 504752.1 & $2 \mathrm{E}-25$ \\
\hline EW9974II & -3.892 & SSH & Lactate/malate dehydrogenase & C. elegans & NP 872154.1 & $5 \mathrm{E}-09$ \\
\hline EW997017 & -3.890 & $\mathrm{SSH}$ & Fumarylacetoacetate hydrolase-related protein & A. thaliana & NP 172669.2 & $2 \mathrm{E}-37$ \\
\hline
\end{tabular}


Table 2: Differentially expressed genes. (Continued)

\begin{tabular}{|c|c|c|c|c|c|c|}
\hline EW99750I & -3.881 & SSH & Unknown & & & \\
\hline EW996972 & -3.875 & $\mathrm{SSH}$ & Unknown ${ }^{6}$ & & & \\
\hline EW997045 & -3.864 & SSH & ATF6 & H. sapiens & BAA34722.1 & 0.0004 \\
\hline CK656733 & -3.830 & ORESTES & Ubiquitin-conjugating enzyme E2D 2 & D. rerio & AAH48896.I & $2 \mathrm{E}-18$ \\
\hline EW997087 & -3.827 & SSH & Unknown & & & \\
\hline EW996855 & -3.824 & SSH & Unknown & & & \\
\hline EW997194 & -3.813 & SSH & Unknown 9 & & & \\
\hline CK6567I3 & -3.797 & ORESTES & Unknown & & & \\
\hline CO87021I & -3.796 & ORESTES & Unknown & & & \\
\hline EW9970I5 & -3.785 & SSH & Unknown & & & \\
\hline EW997I29 & -3.758 & SSH & Unknown & & & \\
\hline EW997449 & -3.757 & SSH & Unknown 5 & & & \\
\hline EW997533 & -3.754 & SSH & Unknown & & & \\
\hline EW997418 & -3.740 & SSH & Hypothetical protein & Aspergillus nidulans & EAA64844.I & $7 E-11$ \\
\hline EW996827 & -3.736 & SSH & Serine 2 transmembrane protease & M. musculus & NP 056590.1 & $4 \mathrm{E}-25$ \\
\hline CK656737 & -3.734 & ORESTES & 70 kDa heat shock protein ${ }^{3}$ & Artemia franciscana & AAL27404.I & $5 \mathrm{E}-59$ \\
\hline CK656706 & -3.723 & ORESTES & M-phase phosphoprotein I & H. sapiens & NP 057279.1 & $4 \mathrm{E}-4$ \\
\hline C0870188 & -3.720 & ORESTES & Cathepsin L-like protease precursor & A. franciscana & $\overline{\mathrm{AAD} 39513.1}$ & $3 \mathrm{E}-5$ \\
\hline EW997548 & -3.683 & SSH & Gnat-family acetyltransferase & Bordetella parapertussis & NP 883664.I & $6 \mathrm{E}-29$ \\
\hline EW9974I2 & -3.677 & SSH & Cytochrome b & Macaca tonkeana & $\overline{\text { AAK26394.I }}$ & $7 E-51$ \\
\hline EW997170 & -3.669 & SSH & Unknown 6 & & & \\
\hline EW996822 & -3.593 & SSH & Unknown & & & \\
\hline EW997067 & -3.569 & SSH & Elongation factor $2^{7}$ & Entamoeba histolytica & $\mathrm{Q} 06193$ & $8 \mathrm{E}-6$ \\
\hline EW997053 & -3.558 & SSH & Elongation factor I-alpha & Coccidioides immitis & Q96WZI & $\mathrm{IE}-12$ \\
\hline CK656707 & -3.550 & ORESTES & Heat shock protein $70^{3}$ & Ambystoma mexicanum & AAK31583.I & IE-67 \\
\hline CK65670I & -3.541 & ORESTES & Unknown & & & \\
\hline EW997447 & -3.511 & SSH & Unknown & & & \\
\hline EW997408 & -3.502 & SSH & Unknown & & & \\
\hline EW996986 & -3.501 & SSH & Ribosomal protein Rps2 & Cricetulus griseus & AAQ94085.I & $6 \mathrm{E}-08$ \\
\hline EW997I07 & -3.483 & SSH & Unknown & & & \\
\hline EW997I05 & -3.478 & SSH & Streptavidin V2 precursor & Streptomyces violaceus & Q53533 & $7 E-5$ \\
\hline EW997I27 & -3.472 & SSH & Cytochrome oxidase subunit I & Platynectes decempunctatus & AANII289.1 & $\mathrm{IE}-40$ \\
\hline EW9968I3 & -3.472 & SSH & Unknown & & & \\
\hline EW996825 & -3.462 & SSH & Unknown 5 & & & \\
\hline EW996824 & -3.461 & SSH & Adenosylhomocysteinase 3 & R. norvegicus & XP 231564.1 & $5 \mathrm{E}-43$ \\
\hline CO870190 & -3.460 & ORESTES & Glutamyl-prolyl-tRNA synthetase & D. melanogaster & NP 52447I.2 & $4 \mathrm{E}-56$ \\
\hline EW997004 & -3.458 & SSH & Unknown & & & \\
\hline EW997180 & -3.435 & SSH & Unknown' & & & \\
\hline EW997569 & -3.430 & SSH & Oligomycin sensitivity conferring protein & D. melanogaster & CAA67980.1 & IE-23 \\
\hline CK656696 & -3.346 & ORESTES & Histidyl-tRNA synthetase & M musculus & $\mathrm{Q} 61035$ & $5 \mathrm{E}-84$ \\
\hline EW997520 & -3.337 & SSH & Copine-related & A. thaliana & NP 564907.1 & $3 \mathrm{E}-70$ \\
\hline EW99705I & -3.324 & SSH & Cytochrome Oxidase subunit $\mathrm{Vb}$ & C. elegans & NP 492601.I & $2 \mathrm{E}-12$ \\
\hline EW997435 & -3.315 & SSH & Unknown & & & \\
\hline CO870229 & -3.300 & ORESTES & Unknown & & & \\
\hline EW997|31 & -3.210 & SSH & Tyrosyl-tRNA synthetase & H. sapiens & AAB39406.1 & $8 \mathrm{E}-26$ \\
\hline EW997037 & -3.151 & SSH & Cytochrome $\mathrm{cl}$ precursor & A. thaliana & NP 198897.1 & $5 \mathrm{E}-44$ \\
\hline DY523263*^ & 3.502 & SSH & Unknown & & & \\
\hline EW996837** & 3.710 & SSH & Unknown & & & \\
\hline DY523267*^ & 3.938 & SSH & Unknown ${ }^{4}$ & & & \\
\hline EW997405 & 4.542 & SSH & Unknown ${ }^{4}$ & & & \\
\hline EW996814* & 5.308 & SSH & Unknown & & & \\
\hline
\end{tabular}

Genes identified as differentially expressed between resistant and susceptible snail lines, ranked in order of mean (across the 4 replicate arrays) fold difference in expression, based on normalized mean intensity ratios. Negative fold difference values indicate resistant-associated clones.

aSource indicates whether the clone was from a suppression subtractive hybridization (SSH) library or open reading frame EST (ORESTES) library.

bThe name, organism, accession number and e-value given for the best match with GenBANK using BLASTX.

* Chosen for qPCR

$\wedge$ also confirmed from SSH experiment

1-9 clusters of overlapping sequences

qPCR result confirmed the result found from the microarray. The difference in expression of all of these genes was much greater than that indicated in the array; in many cases the transcript was barely detectable in the strain which showed less expression from the microarray. This confirms the suggestion that SMART amplification compresses the observed expression ratio and may also suggest that the fold difference in gene expression observed from 


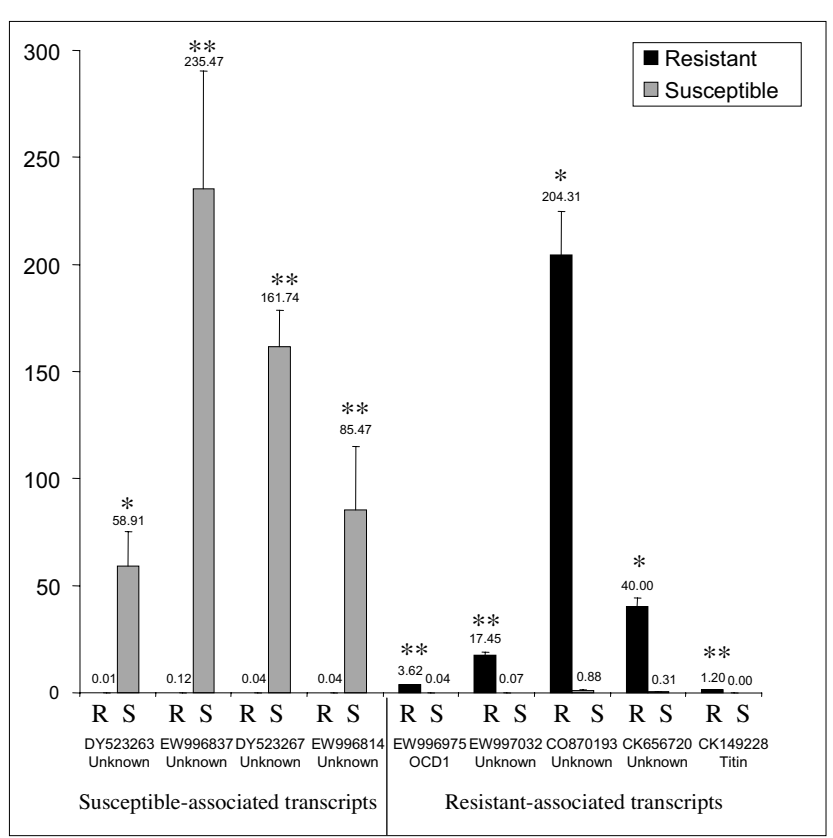

\section{Figure 2}

Histogram showing relative (normalized against actin) expression from qPCR for 9 genes in unamplified cDNA from schistosome-exposed resistant and susceptible snails. The $P$ values from a students $t$-test demonstrated $*<0.05$ or $* *<0.0$ I significance.

the microarray underestimates the true difference in expression of transcripts.

All the identified differentially expressed genes were originally sequenced from haemocyte libraries (Fig. 3); although many other transcripts were present in the samples, they were not differentially expressed. Just over a quarter $(25.7 \% ; n=27)$ of the differentially expressed genes were from ORESTES and the remaining from SSH. Clustering the identified differentially expressed sequences revealed 9 clusters, one with 5 sequences and 8 with two (Table 2), leaving 98 unique sequences or clusters. One of the clusters contained two susceptible specific sequences leaving 4 unique susceptible and 94 resistant specific sequences. All of the susceptible-specific transcripts had no database matches and were derived from SSH. They included 2 sequences (DY523263 and cluster 4 - DY523267/EW997405) that had previously been identified as differentially expressed between resistant and susceptible snail haemocytes by screening macroarrays of SSH clones and confirmed with RT-PCR [27].

\section{Annotation of identified sequences}

Sixty of the 98 sequences or clusters did not identify other GenBank sequences in BlastX searches (Table 2) and were categorized as genes with unknown function. The func-

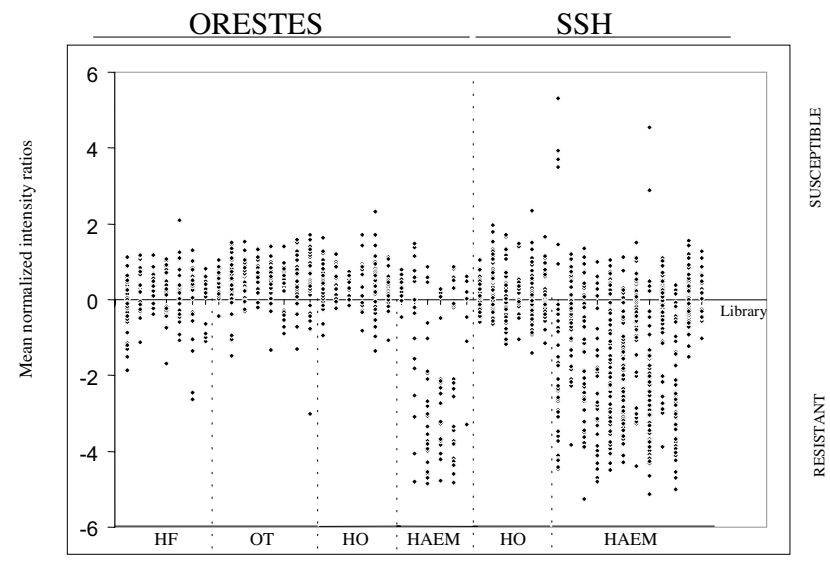

Figure 3

Scatter plot of mean (across the 4 replicate arrays) fold difference in expression, based on normalized mean intensity ratios across each sequenced library, demonstrating the origin (tissue and method) of the differentially expressed genes. ORESTES - open reading frame EST libraries, SSH - suppression subtractive hybridization libraries. OT - ovotestis, HAEM - haemocytes, HO haemopoietic organ, HF - headfoot.

tions of the other identified genes were more closely examined using gene ontology and KEGG pathway analysis. Gene ontologies were assigned for 29 genes of the 110 differentially expressed transcripts (Fig. 4), including, among other genes (see Table 2); titin (CK149228), importin 7 (EW997446), copine 1 (EW997520), elongation factor $1 \alpha$ (EF-1 $\alpha$ : EW997053) and EF-2 (EW997067/ EW997555 in cluster 7) and the stress response protein HSP70 (CK656737/CK656707 in cluster 3). KEGG pathway analysis identified 24 enzymes with 27 clones in a number of metabolic pathways (Table 3), including malate dehydrogenase (EW997411) involved in carbohydrate metabolism; six genes involved in oxidative phosphorylation in energy metabolism and six clones involved in amino acid metabolism including two clones homologous to ornithine decarboxylase 1 (ODC1) (EW996975 and EW996976). Although both sequences identified ODC1 in blast searches, they did not cluster at the nucleotide level, despite identifying overlapping protein sequence and are likely to be paralogous. Two genes coding for ODC1 have been found in both Xenopus laevis [31] and Drosophila melanogaster [32]. Six genes involved in translation were identified as well as the ubiquitin conjugating enzyme, UBE2D/E (CK656733), involved in folding, sorting and degradation. We also identified one sequence with a weak homology to cathepsin L cysteine protease (CO870188), involved in degradation of exogenous and endogenous proteins in lysosomes. The function of these genes and their potential involvement in the snail IDS is discussed further below. 
Table 3: KEGG pathways identified by differentially expressed genes.

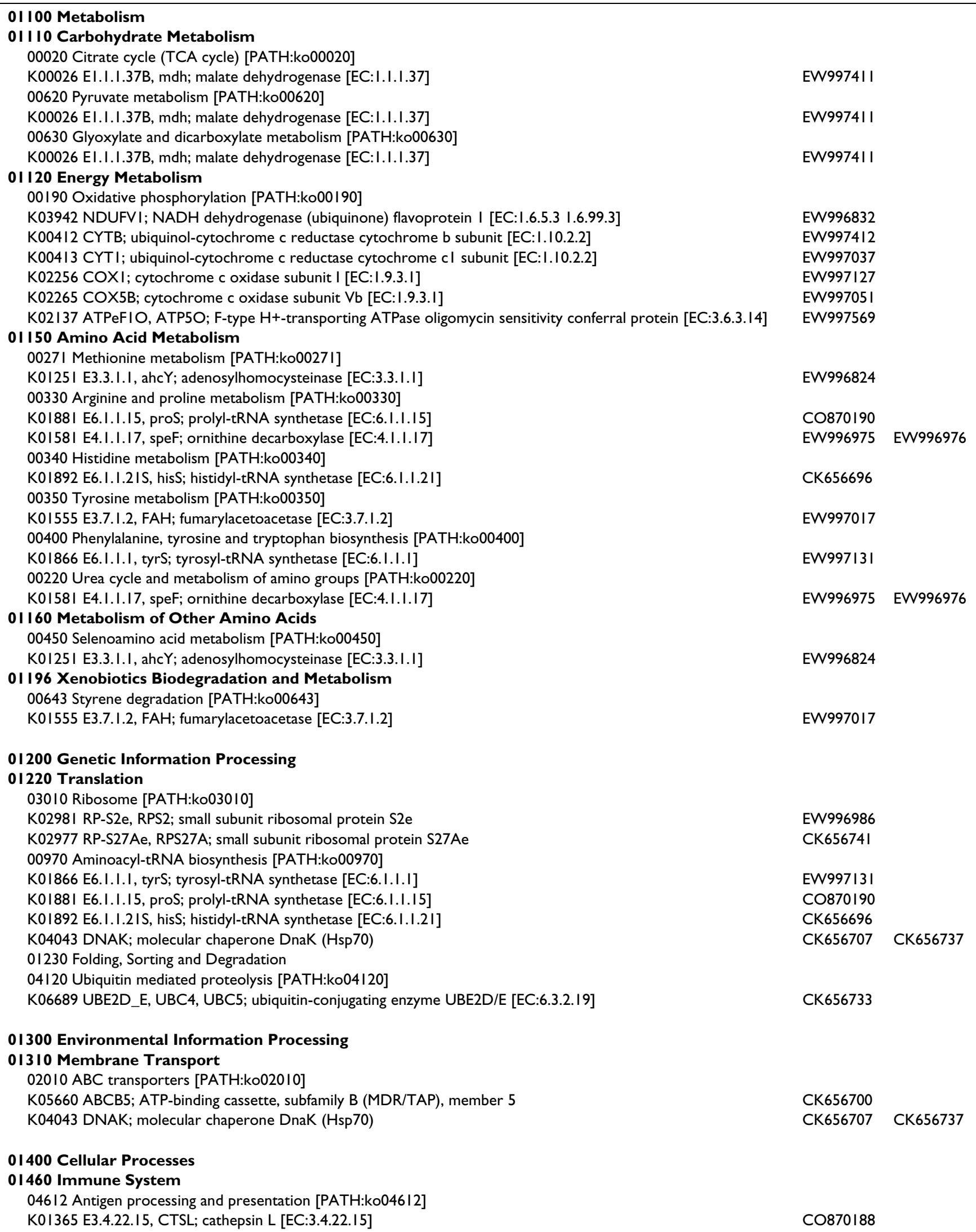


Table 3: KEGG pathways identified by differentially expressed genes. (Continued)

\begin{tabular}{ll}
\hline Unclassified & EW996827 \\
K01346 pancreatic elastase II & EW997053 \\
K0323I elongation factor EF-I alpha subunit & EW997067 EW997555 \\
K03234 elongation factor EF-2 & EW996808 \\
K08884 serine/threonine protein kinase & EW997045 \\
K09054 activating transcription factor 6 & \\
\hline
\end{tabular}

Pathways identified by genes found only in the parasite-exposed resistant snails.

\section{Discussion}

A B. glabrata cDNA microarray was successfully constructed consisting of 2053 clones from headfoot, ovotestis, haemopoeitic organ and haemoctyes of two different strains of B. glabrata. Screening the array with RNA from haemocytes of schistosome-exposed resistant and susceptible snail strains identified 98 differentially expressed genes or gene clusters. There was little difference between technical replicates indicating that there were no sampling effects from amplifying small amounts of starting RNA, giving confidence in the assignment of strain-associated differential expression. Examination of the expression of 9 selected genes using real-time RT-PCR on unamplified cDNA confirmed differential expression in each case.

Most of the genes identified (95.9\%) were present only in the resistant snail line. That only a few differentially expressed genes were identified in susceptible snails may be due to the failure of the snail's defence system to recognize the parasite, possibly because $S$. mansoni sporocyts may mimic snail moieties (molecular mimicry) or because they may rapidly acquire molecules from the host with which to disguise themselves [33]. Alternatively, $S$. mansoni sporocysts may actively suppress a humoral response in susceptible hosts. In either case the transcripts identified in the resistant snails are genes, either constitutively over-expressed in resistant snails, not suppressed in resistant snails, or activated when the snail does recognize the parasite's presence and responds. Of the 4 genes, or gene clusters, identified in susceptible snails, two (DY523263 and cluster 4: DY523267/EW997405) had been previously identified and confirmed as differentially expressed in our earlier experiments [27] suggesting that they are consistently differentially expressed by susceptible snails. Since none has a known function it is difficult to speculate on their possible role(s).

Over half $(63.8 \%)$ of the genes identified with higher expression levels in the resistant snails have no known function. Although many of these may play a significant role in defence, further characterization of their function is required to ascertain what that role might be in the snail IDS. Of the ESTs with homology to known genes, the observed differential expression of genes involved in energy metabolism, in particular oxidative phosphorylation, amino acid metabolism and genetic translation, indicates a general increase in cellular activity, consistent with generating the necessary components for mounting a defensive response. For example, EF-1 $\alpha$ (EW997053) and EF-2 (EW997067/EW997555 in cluster 7), as well as several other proteins involved in protein synthesis, were identified, including crooked neck-like 1 protein (CK656728) involved in pre mRNA splicing. Differential expression of these types of transcripts suggests an increase in general cell activity, with increased production of new proteins in response to infection in the resistant compared to the susceptible line.

Two paralogous ornithine decarboxylase (EC 4.1.1.17) ODC1 gene fragments (EW996975 and EW996976) were identified as differentially expressed in resistant snails. ODC is the first and rate-limiting enzyme in the polyamine biosynthesis pathway, which decarboxylates Lornithine (a product of arginase activity) to form putrescine. Polyamines (putrescine, spermidine and spermine) regulate gene expression, modulate cell signalling and are required for normal cell proliferation, important in inflammatory and infection processes [34]. Polyamines have been described as primordial stress molecules with defensive functions against diverse stresses [35], including protecting cells from DNA strand breakage induced by reactive oxygen species (ROS) and functioning directly as free radical scavengers [36,37]. Generation of ROS has been shown to play a role in sporocyst killing by molluscan haemocytes in incompatible snail-trematode systems $[38,39]$. Production of polyamines could protect the resistant snail's own cells from the damaging effects of ROS.

The identification of ODC in resistant snails may also imply activation of arginine metabolic pathways, which play an important role in inflammation and wound healing $[40,41]$. Increased levels of ODC in resistant snails indicate production of the substrate L-ornithine, inferring the depletion of L-arginine by arginase activity and subsequent inhibition of nitric oxide (NO) preventing damage to host cells. L-arginine (L-arg) is the substrate for both arginase (produces L-ornithine and urea) and nitric oxide synthase (NOS) (produces L-citrulline and NO). In inflammatory diseases, it is thought that NO production from L-arg is involved in the initial early host response creating an overall cytotoxic environment, whilst L-orni- 

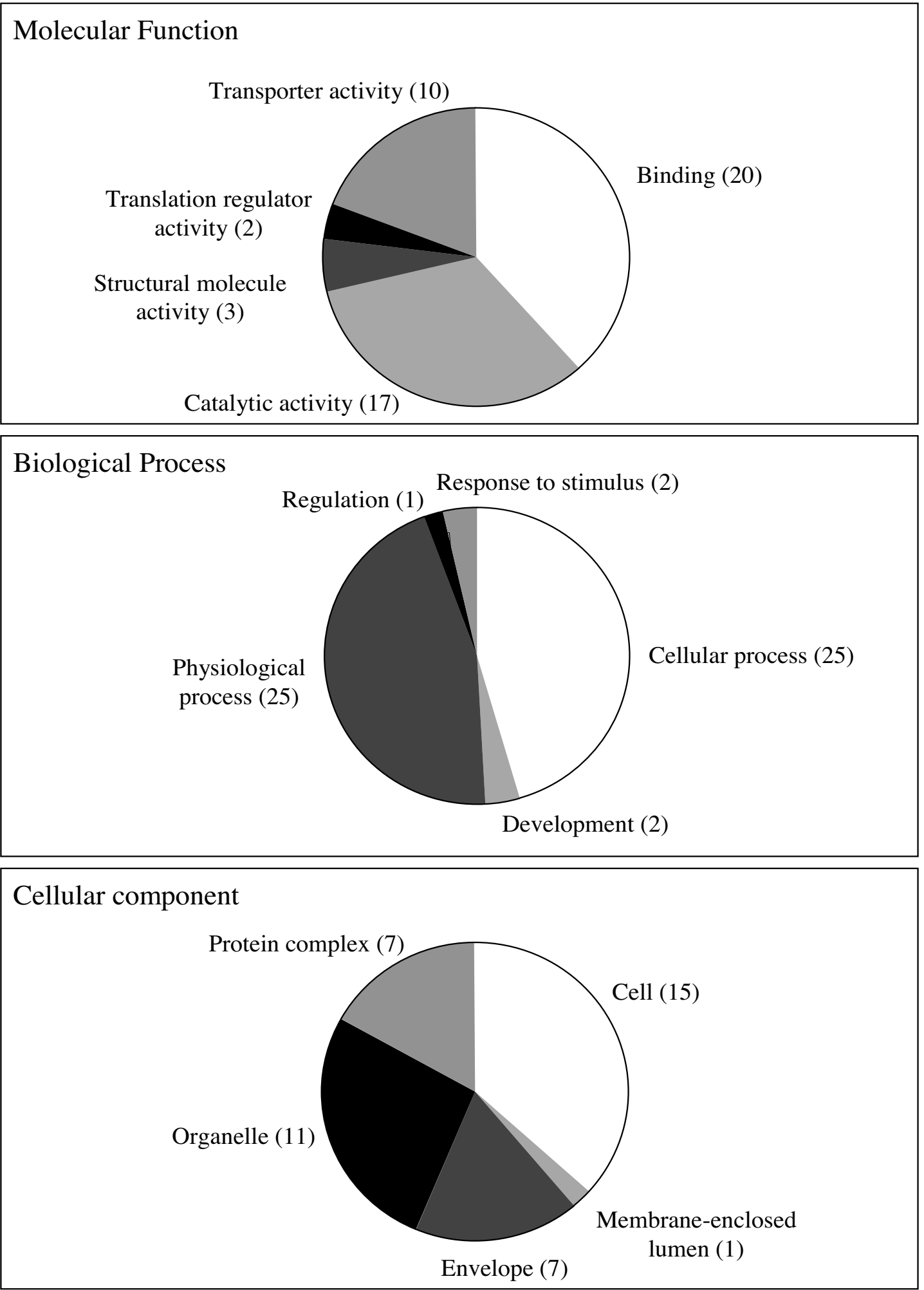

Figure 4

Gene ontologies for the 29 (of I I0) differentially expressed genes that had GO matches. All those shown here are resistant specific, since the susceptible-specific genes identified no homologous genes. 
thine production from L-arg is involved in healing, promoting cell growth and proliferation $[42,43]$. In its role as host defender, NO regulates inflammatory responses and acts as an effector molecule of haemocyte cytotoxicity against invaders (such as parasites), whilst at the same time when produced in excessive amounts, NO is cytotoxic not only to the invading schistosome but also to the snail hosts own cells. Hence, infected snail hosts must strive to find a balance between anti-schistosome and cytotoxic effects of NO towards its own cells. NO has been shown to mediate host-protective responses in a variety of parasitic infections [44] including the killing of $S$. mansoni sporocysts by haemocytes from resistant $B$. glabrata [45]. Differential expression of ODC in resistant snails may suggest an involvement in snail defence by scavenging the damaging free radicals produced during the production of ROS by haemocytes for cytotoxic killing of sporocysts; in regulating production of cytotoxic NO by depleting the competing substrate; or, with the production of polyamines leading to DNA protection and cell proliferation, aiding wound healing following miracidial penetration.

Also identified as differentially expressed in the resistant snail line, HSP70 (CK656737/CK656707 in cluster 3) was previously identified, using differential display, as upregulated only in the resistant snails after parasite exposure [21], verifying our original suggestion that upregulation of HSP70 is an expected response to infection, and is absent from the susceptible snails. The induction of heat shock or stress proteins represents a homeostatic defence mechanism of cells to metabolic and environmental insults, and this response has previously been demonstrated in molluscs, for example in oyster haemocytes in response to environmental stimulus [46]. Experiments with mollusc haemocytes derived from Crassostrea gigas and Haliotis tuberculata demonstrated that the HSP70 gene promoter is induced by noradrenaline and $\alpha$-adrenergic stimulations [47] showing that the response in these cells is integrated with neuroendocrine signalling pathways.

Several proteins potentially involved in cell signalling were also identified in the resistant snails only. One transcript (CK149228) was found to be homologous to titin (sometimes known as connectin), which is a giant springlike protein responsible for passive tension generation and for positioning of the thick filament at the centre of vertebrate striated muscle sacromeres. This protein has multiple elastic and signalling functions derived from a complex subdomain structure, including a series of immunoglobulin (Ig) domains. The kinase domain of titin initiates a signal transduction cascade that controls sarcomere assembly, protein turnover, and transcriptional control in response to mechanical changes in vertebrates [for review see [48]]. Smaller but related molecules have been identified in invertebrate striated or smooth muscles, variously named mini-titins, projectins or twitchins (in molluscs), depending on their origin $[49,50]$. The expression of this gene in resistant snails may indicate a signalling or muscle response to parasite infection that is not initiated in susceptible snails. In addition to titin, a cytoplasmic intermediate filament (IF) protein (CK656726) was identified only in the resistant snails. Rather than merely providing a cellular framework, recent research has demonstrated that IFs are dynamic, motile elements of the cytoskeleton in vertebrate cells [51]. An IF protein has previously been identified in B. glabrata, using a comparative proteomic approach, as differentially expressed in snails resistant to E. caproni [52] and it was suggested that this gene could be a candidate to explain differences in susceptibility/resistance, considering the major role of haemocyte mobility and adherence capabilities in defence to the parasite. Interestingly, uninfected susceptible snails demonstrated higher levels of the IF gene transcript; however post-exposure to the parasite the resistant snails showed a significant increase in transcript levels, while susceptible snails had a decrease. Our sequence does not identify this transcript either at the nucleotide or protein level and demonstrates close homology (e-value: 6.4e-25) to a neuronal IF, neurofilament protein NF70 from Helix aspersa [53] one of the type IV IFs. It has also been suggested that some IFs participate in signalling processes by providing a scaffold to bring together activated MAP kinases (such as extracellular signal-regulated kinase, ERK) with other molecules [54].

Other molecules potentially involved in signaling processes in the cell are importin 7 and copine 1. A gene fragment homologous to importin 7 (EW997446) was identified in the resistant snails. This protein functions as a nuclear import cofactor, and in Drosophila, has been implicated in the control of multiple signal transduction pathways, including the direct nuclear import of the activated (phosphorylated) form of MAP kinase (ERK) [55]. $S$. mansoni excretory secretory products (ESPs) and whole sporocysts have been shown to affect ERK signalling in the haemocytes of susceptible snails, but not resistant ones [56] suggesting that the disruption of ERK signalling in haemocytes facilitates $S$. mansoni survival within susceptible B. glabrata. Another gene, copine 1 (EW997520), implicated in membrane trafficking [57] and signal transduction [58] was identified in the resistant snails. Copine 1 is a calcium-dependent membrane binding protein which, in mammals, has been shown to regulate the NF kappa B transcriptional responses [59]. In Arabidopsis thaliana, copine 1 is suggested to play a role in plant disease resistant responses, possibly as a suppressor of defense responses including the hypersensitive cell death response [60]. 
We identified two hydrolytic enzymes in haemocytes from the resistant snail line, elastase (EW996827) and cathepsin L-like protease precursor (CO870188), also known as cysteine proteinase. Higher levels of cysteine proteinase activity have previously been observed in hepatopancreas extracts from resistant (BS-90) B. glabrata when compared to susceptible (M-line) snails [61]. Cathepsin L, cathepsin B and elastase were also identified among other hydrolytic enzymes from a hepatopancreas EST library derived from resistant snails and cathepsin B demonstrated greater up-regulation in resistant snails compared to susceptible snails upon parasite exposure [61]. In invertebrates, cysteine proteases play a major role in the lysosomal proteolytic system, responsible for intracellular protein degradation [62]. This role, in the lysis of phagocytosed particles, may be significant in the breakdown of encapsulated sporocysts or phagocytosed parasite components. In addition to a role as a scavenger for the clearance of unwanted proteins, this protease plays an important role in antigen processing and presentation in mammalian immune systems $[63,64]$ and lysosomal proteases have been implicated in innate immunity in insect haemocytes [65]. Genome-wide analysis of immune challenged Drosophila revealed elevated expression of cathepsin L when infected with either Gram-positive bacteria or fungi [66]. Similarly, cathepsin L was highly expressed in WSSV (white spot syndrome virus) resistant shrimp, suggesting that it is involved in defence responses [67]. A cathepsin L-like gene (EE049537) has previously been identified in B. glabrata susceptible to Echinostoma caproni infection [68]. Our sequence (CO870188) does not cluster with this and identifies (by BLAST) a cathepsin-like domain 3' to sequence identified by the other gene fragment, suggesting that the ESTs may be two non-overlapping parts of the same gene. The discrepancy between the observed changes in gene expression may be due to the different response elicited by two different parasite species. S. mansoni fails to produce a response in susceptible snails as they fail to recognise the presence of the parasite, while in echinostome infections a defence response may be mounted by the snail, but is interfered with by the parasite [69].

Differential expression of ubiquitin conjugating enzyme (UBE2D/E) E2 (EC6.3.2.19) (EW997520) was detected in exposed resistant snails and may indicate removal of the phagocytosed sporocyst. Ubiquitination plays an important role in various cellular functions including apoptosis, cell cycle progression, transcription and endocytosis [70]. A major role is regulating the half-life of proteins by targeting them for $26 \mathrm{~S}$ proteasomal degradation, removing denatured, damaged or improperly translated proteins.

In this study we compared haemocytes obtained from resistant and susceptible snail strains 2 to $24 \mathrm{~h}$ after exposure to $S$. mansoni, and have found differentially expressed transcripts potentially involved in a range of responses from signalling and inflammation responses through to lysis of proteinacous products (e.g. encapsulated sporocysts, or phagocytosed parasite components) and processing/degradation of such targeted products by ubiquitination. In future, examination of biological replicates will increase the confidence that the transcripts identified in this study are truly significant in the snail IDS, in addition to demonstrating the amplification techniques utilized in this study are robust. Examination of a series of narrower time slots will enable us to unravel the sequence of processes involved and highlight genes initiating the cascade in resistant (responsive) hosts. A simultaneous comparison of both parasite-exposed and unexposed snails from both snail lines will also determine if the basis of the snail's resistance is due to an underlying difference in gene expression between the strains, or from differences in their response to the parasite. Such comparisons may also be significant in determining why susceptible snails do not respond to infection, either by non-recognition of invading parasite or by active suppression of innate response by the parasite, which may be indicated if $S$. mansoni-exposure results in significantly more down-regulated genes in susceptible snails. At present we can only speculate on the function in B. glabrata of the genes identified. Future expression experiments involving RNAi or in situ hybridization may elucidate their role in resistance.

\section{Conclusion}

In conclusion, the advent of the first CDNA microarray for B. glabrata leads the way for detailed analysis of the B. glabrata transcriptome and can be developed further to include more cDNAs as these become available. The array described here is particularly suited for analysis of snail haemocytes and their role in the snail IDS since it contains a large proportion of genes sequenced from haemocytes. Despite the current limited size of the array, prior enrichment for differentially expressed genes using the SSH approach has enabled us to identify a number of genes and pathways differentially expressed in the resistant snail line and potentially involved in the defence of resistant snails to schistosome infection. These include hydrolytic enzymes such as elastase and the cysteine protease, cathepsin $\mathrm{L}$; ornithine decarboxylase, involved in the production of polyamines; HSP70; potential signalling molecules importin 7 and copine 1 and transcription enzymes such as EF-1 $\alpha$ and EF-2. Continued development of this array has great potential for examining and understanding the functions of the B. glabrata transcriptome.

\section{Methods \\ SSH library sequencing and bioinformatic analysis}

8 SSH libraries were available for sequencing [27]. 192 clones $(2 \times 96)$, selected at random from each library, were picked into $0.5 \mathrm{ml} \mathrm{LB}$ and grown up overnight. $10 \mu \mathrm{l}$ 
PCRs with M13 forward and reverse primers were carried out to check insert size and the presence of a single insert and, from these, 96 colonies were chosen for $100 \mu$ l PCRs. PCRs contained $1 \times \mathrm{NH}_{4}$ reaction buffer (Bioline, London, UK), $2.5 \mathrm{mM} \mathrm{MgCl}_{2}, 0.2 \mathrm{mM}$ dNTP, $0.2 \mu \mathrm{M}$ each M13 Forward and Reverse primers and $0.025 \mathrm{U} / \mu \mathrm{l}$ PCR Taq polymerase (Bioline, London, UK). Cycling conditions were: $94^{\circ} \mathrm{C}$ for $2 \mathrm{~min}$, then 35 cycles of $94^{\circ} \mathrm{C}$ for $30 \mathrm{sec}$, $58^{\circ} \mathrm{C}$ for $30 \mathrm{sec}$ and $72^{\circ} \mathrm{C}$ for $1 \mathrm{~min} 30 \mathrm{sec}$, then $10 \mathrm{~min}$ at $72^{\circ} \mathrm{C}$. Glycerol stocks for the selected colonies were stored at $-80^{\circ} \mathrm{C}$. PCR products were purified using Multiscreen PCR filter plates (Millipore, Billerica, USA) then cycle-sequenced directly using BigDye kit (Applied Biosystems, Foster City, USA) and T7 primer and run on ABI 377 or capillary sequencers. Vector, primer and poor quality sequences were removed using Sequencher 3.1.1 (GeneCodes Corp., Ann Arbor, USA.). Cluster analysis was performed in SeqTools http://www.seqtools.dk/ using BlastN score values (cutoff value 0.5 ) and used to calculate percentage redundancy. For each library BlastN and BlastX [71] searches were run and ribosomal, short ( $<80 \mathrm{bp}$ ) and duplicate sequences were removed, although overlapping sequences were retained. Duplicate sequences between libraries were retained. Sequences were submitted to GenBank (EW996689-EW997658). Gene Ontology functions were assigned using GOblet http://goblet.mol gen.mpg.de/. KEGG (Kyoto Encyclopaedia of Genes and Genomes) pathway analysis was carried out using the KEGG automatic annotation server (KAAS) for ortholog assignment and pathway mapping http:// www.genome.jp/kegg/kaas/.

\section{Microarray construction}

1062 ORESTES clones available from the first 27 ORESTES libraries [6] (GenBank numbers CK149151CK149590, $\quad$ CK656591-CK656938， CO870449, $\underline{\text { CV548035-CV548805, EG030731- }}$ $\underline{\text { EG030747) }}$ and $980 \mathrm{SSH}$ clones (GenBank numbers EW996689-EW997658) were picked using a Microlab Star robotic work station (Hamilton) and transferred to 384 well plates. 11 clones from our previous differential display studies were also included (GenBank numbers $\underline{\text { CK136129, }}$ CK136132-CK136138) including a HSP70 sequence; a gene coding for a protein with globin-like domains and several genes with unknown functions which were shown to be upregulated in the resistant snail line after parasite exposure [21], as well as 3 clones containing overlapping regions of CYP320A (GenBank Accession AY922309) [72] which was identified from a $70 \%$ resistant snail line [20]. A total of 2053 cDNA clones (50$200 \mathrm{ng} / \mu \mathrm{l})$ were printed in duplicate within each subarray. Controls were also included: yeast tRNA $(250 \mathrm{ng} / \mu \mathrm{l})$; B. glabrata genomic DNA, NHM3017, NHM1742 (200 $\mathrm{ng} / \mu \mathrm{l})$; pGem (purified vector with no insert) $(75 \mathrm{ng} / \mu \mathrm{l})$, two specific genes, (ribosomal 18s and cytochrome oxi- dase I) amplified from S. mansoni and blanks containing spotting buffer only. $15 \mu \mathrm{l}$ aliquots were transferred to a second 384 well plate (Genetix) and $5 \mu \mathrm{l} 4 \times$ spotting buffer (600 mM sodium phosphate; $0.04 \%$ SDS) added. The clones were printed in 16 subarrays ( 4 columns $\times 4$ rows), with $18 \times 17$ clones in each subarray, and, since the size of the array allowed it, two arrays were printed per aminopropyl silane coated glass slide (GAPSII, Corning, at the Microarray facility at Dept of Pathology, Cambridge University), using a Lucidea arrayer (Amersham Biosciences). Microarrays were processed by baking for $2 \mathrm{~h}$ at $80^{\circ} \mathrm{C}$ and UV cross-linking at $600 \mathrm{~mJ}$.

\section{Snail material and parasite exposure}

60 adult $B$. glabrata snails from susceptible line (NHM Accession number 1742) and 60 from resistant line (NHM Accession number 3017, derived from BS-90 [73]) were held overnight in autoclaved snail water with 100 $\mu \mathrm{g} / \mathrm{ml}$ ampicillin. Each snail was individually exposed to 10 S. mansoni miracidia (Belo Horizonte strain). Samples of 12 resistant and 12 susceptible snails were taken at 5 time periods, starting at 2, 4, 6, 8 and $24 \mathrm{~h}$ after exposure to the parasite. The extended sampling was designed to include all transcripts expressed over the first $24 \mathrm{~h}$ post parasite exposure. Snails were swiftly killed by decapitation, and the exuded haemolymph collected. Haemolymph was pooled for each sampling time and snail strain, and haemocytes pelleted by spinning at $10,000 \mathrm{~g}$ at $4{ }^{\circ} \mathrm{C}$ for $20 \mathrm{~min}$. The pellet was frozen in liquid nitrogen and stored at $-80^{\circ} \mathrm{C}$.

\section{Microarray hybridization}

Total RNA was extracted from haemocytes pooled from all the time periods, using SV RNA extraction kit (Promega UK Ltd, Southampton, UK) according to the manufacturer's protocol. This kit includes DNAse treatment to eliminate genomic DNA contamination. cDNA was synthesized from $500 \mathrm{ng}$ total RNA using the Smart PCR cDNA synthesis kit (BD Biosciences) according to the manufacturer's instructions and was labelled with $\mathrm{Cy} 3$ or Cy5 using the BioPrime DNA labelling system (Invitrogen). The labelled products were purified (Auto-seq 50 columns, Amersham), combined and precipitated. Before hybridization the microarray slides were prehybridized with hybridization buffer (40\% formamide, $5 \times$ Denhardts, $5 \times$ SSC, $1 \mathrm{mM}$ Sodium pyrophosphate, $1 \mathrm{mM}$ Tris and $0.1 \% \mathrm{SDS}$ ) at $50^{\circ} \mathrm{C}$ for $1 \mathrm{~h}$. The combined labelled cDNA was re-suspended in $40 \mu \mathrm{l}$ hybridization solution, denatured at $95^{\circ} \mathrm{C}$ for $5 \mathrm{~min}$ then $50^{\circ} \mathrm{C}$ for $5 \mathrm{~min}$, spun down, then applied to the array. Hybridizations were carried out at $50^{\circ} \mathrm{C}$ for $16-18 \mathrm{~h}$ in a humidified chamber. 3 independent SMART amplifications were made from the synthesized cDNA and 4 hybridizations were performed, including one dye swap. The slides were washed with 2 successive 5 min washes in $2 \times$ SSC at room temperature 
with agitation, then two in $0.2 \times$ SSC/0.1\% SDS, then two in $0.1 \times$ SSC, each for $5 \mathrm{~min}$ and dried by spinning.

\section{Microarray scanning and analysis}

Microarray slides were scanned sequentially for each Cy dye, at $10 \mu \mathrm{m}$ resolution using an Axon GenePix 4100A scanner. The PMT (photo multiplying tube) was adjusted to give an average intensity ratio between channels of approximately 1 . Spot finding and intensity analysis was carried out using GenePix Pro 5.0. The results were exported to Acuity 4.0. The mean pixel intensity (Feature(wavelength)-Background(wavelength)) was normalized using intensity-dependent lowess normalization for each feature [74] and consistency within each array was assessed by comparing normalized mean pixel intensity ratios (Cy3/Cy5) for each duplicate feature. Poor quality spots and low intensity data were removed. For each array the mean intensity values for pGem (vector) controls was calculated to give a background level of hybridization and only features with higher intensities than the mean plus one standard deviation threshold in either channel (Cy3 or Cy5) were retained. Consistency between array replicates was assessed by comparing mean (from the two duplicates) intensity ratios for each clone. The mean and $\mathrm{SD}$ of the remaining data, excluding SSH clones, were used to calculate $99 \%$ confidence limits for the normalized intensities for each array and those features which showed differential expression outside this 99\% level marked. Genes that passed the $99 \%$ confidence level in 3 or 4 of the arrays were considered to demonstrate differential expression. The data from this microarray experi- ment has been deposited with ArrayExpress: accession EMEXP-1710.

\section{Quantitative real-time PCR}

Several clones were chosen for confirmation of differential expression using real-time (quantitative) PCR. Primers were designed for 9 clones and actin (Table 4) using Primer Express software (Applied Biosystems) and used for qPCR. PCRs contained Power SYBR ${ }^{\circledast}$ Green Master Mix according to the manufacturers protocol (Applied Biosystems), $10 \mathrm{pmol}$ of each primer and used $1 \mu \mathrm{l}$ of $1 / 5$ dilution of cDNA from resistant and susceptible haemocytes. PCR cycling conditions were: $50^{\circ} \mathrm{C}$ for $2 \mathrm{~min}, 94^{\circ} \mathrm{C}$ for 10 min, then 35 cycles of $94^{\circ} \mathrm{C}$ for $30 \mathrm{sec}, 58^{\circ} \mathrm{C}$ for $30 \mathrm{sec}$ and $60^{\circ} \mathrm{C}$ for $1 \mathrm{~min}$, using the PRISM ${ }^{\circledast} 7000$ Sequence Detection System (Applied Biosystems). A dissociation curve was generated in each case to check that only a single band was amplified. The results were analyzed using qGene [75]. Amplification efficiency curves [76] were generated by pooling and serially diluting the resistant and susceptible secondary PCRs generated for the SSH libraries [27] and the CT values (the cycle at which the fluorescence rises appreciably above background fluorescence) of the qPCRs were normalized to actin taking into account the amplification efficiency of each primer. Mean normalized expression (MNE') was calculated according to the equation:

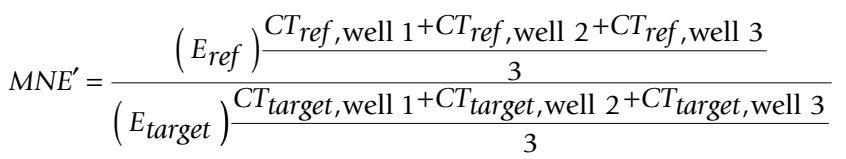

Table 4: qPCR primers for selected candidates

\begin{tabular}{|c|c|c|c|c|}
\hline Primer name & Gene name & Sequence $5^{\prime}-3^{\prime}$ & Product size (bp) & $\mathrm{R} / \mathrm{S}^{\mathrm{a}}$ \\
\hline DY523263F & Unknown & ACGTAGGAGACTGAGGGCACC & 151 & $\mathrm{~S}$ \\
\hline DY523263R & & CAAATCCTCAAATATGCACGAAAC & & \\
\hline EW996837F & Unknown & AACCGAATCAGAGGCGACAG & 143 & $\mathrm{~S}$ \\
\hline EW996837R & & CCGAGCATGGAATGGAAGAG & & \\
\hline DY523267F & Unknown & TGGTGATAAATGCTCTGGTAGCTC & 117 & $\mathrm{~S}$ \\
\hline DY523267R & & CAGCAATATAATCAAAGGGCAATG & & \\
\hline EW9968I4F & Unknown & GTGAAGAATTGAGGATTGAACATCC & 113 & $\mathrm{~S}$ \\
\hline EW9968I4R & & GAACCACCACATAGCGCAAAG & & \\
\hline EW996975F & ODCI & ACTTTTGATAAGGTGGGTTCTTCG & 135 & $\mathrm{R}$ \\
\hline EW996975R & & TGCTGAATCTATCCGACTGGC & & \\
\hline EW997032F & Unknown & TTAGTTGCAGGAGGAGGCTTAGC & 116 & $\mathrm{R}$ \\
\hline EW997032R & & CCGCTTGCACCGTATGATG & & \\
\hline CO870193F & Unknown & CAACTGGGTTGGGATCGTG & 130 & $\mathrm{R}$ \\
\hline CO870I93R & & CCTGAACAATTCGGTCTCAGC & & \\
\hline CK656720F & Unknown & AAACTTGATGTGCGACTGATGG & 96 & $\mathrm{R}$ \\
\hline CK656720R & & CAAAATCATCTTCTGGGTAAAGGG & & \\
\hline CKI49228F & Titin & GTGAATCTGAACCATGCGACTTAG & 106 & $\mathrm{R}$ \\
\hline CKI49228R & & GCACCATCGTCAATCGTACG & & \\
\hline ACTINRTF & Actin & TATGTGCAAGGCAGGTTTCG & 113 & $\mathrm{C}$ \\
\hline ACTINRTR & & AGCTGTCCTTCTGACCCATACC & & \\
\hline
\end{tabular}

a R - resistant associated, S- susceptible associated, C- control. 
where $\mathrm{E}_{\text {target }}$ is the PCR amplification efficiency of the target gene; $\mathrm{E}_{\mathrm{ref}}$ is the PCR amplification efficiency of the reference gene; $\mathrm{CT}_{\text {target }}$ is the threshold cycle of the PCR amplification of the target gene and $\mathrm{CT}_{\text {ref }}$ is the threshold cycle of the PCR amplification of the reference gene [using Equation 3, see [75]]. Reactions were carried out in triplicate and a Student's t-test ( 2 samples, 2 tailed distribution) used to determine significant difference in expression between the two snail lines.

\section{Authors' contributions}

AEL constructed the microarray, performed microarray experiments and analysed the microarray data, assisted by CSJ, and analysed real-time PCR data and wrote the manuscript. JS sequenced the SSH clones and assisted in the construction of the microarray. JMF and KFH helped with initial microarray analyses. RAK carried out the qPCR. DR, LRN and CSJ were involved in the experimental design and drafting of the manuscript. All authors read and approved the final manuscript.

\section{Additional material}

\section{Additional file 1}

KEGG pathway analysis. A comparison of KEGG pathways identified by Biomphalaria glabrata ESTs from ORESTES and SSH, using the nonredundant dataset of ESTs for each.

Click here for file

[http://www.biomedcentral.com/content/supplementary/14712164-9-634-S1.doc]

\section{Additional file 2}

Scatter plots comparing mean (of duplicate spots within arrays) normalized intensity ratios for each gene between replicate array hybridizations of pooled haemocyte material. The correlation coefficients suggest a high level of correlation and a low level of variation among independent hybridizations from the technically replicated experiments. The data were previously screened to remove values below threshold levels. Clones for which data were missing in one of the compared arrays were discarded from the plot. Lines represent the line of regression (centre line) and the predicted $99 \%$ confidence intervals of the plotted data.

Click here for file

[http://www.biomedcentral.com/content/supplementary/14712164-9-634-S2.pdf]

\section{Acknowledgements}

This work was carried out with funding from the Wellcome Trust (068589/ Z/02/Z). We would like to thank Aidan Emery, Jayne King and Mike Anderson, NHM, for snail and parasite culture, Claire Griffin, NHM, for sequencing assistance, and Julia Llewellyn-Hughes and Steve Llewellyn-Hughes for using the Microlab Star robotic work station (Hamilton) to pick the clones. The microarrays were printed at the Department of Pathology, Cambridge University, by Anthony Brown and David Carter. Cathy Jones was in receipt of a Royal Society of Edinburgh Sabbatical Fellowship whilst coauthoring this article.

\section{References}

I. Chitsulo L, Loverde R, Engels D, Barakat R, Colley D, Cioli D, Feldmeier H, Loverde P, Olds GR, Ourna J, et al.: Schistosomiasis. Nature Reviews Microbiology 2004, 2:I2-I3.

2. Saavedra C, Bachere E: Bivalve genomics. Aquaculture 2006, 256: I- I4.

3. Tanguy A, Bierne N, Saavedra $C$, Pina $B$, Bachère $E$, Kube $M$, Bazin $E$, Bonhomme F, Boudry P, Boulo V, et al:: Increasing genomic information in bivalves through new EST collections in four species: Development of new genetic markers for environmental studies and genome evolution. Gene 2008, 408:27-36.

4. Davison A, Blaxter ML: An expressed sequence tag survey of gene expression in the pond snail Lymnaea stagnalis, an intermediate vector of Fasciola hepatica. Parasitology 2005, 130:539-552.

5. Mitta G, Galinier R, Tisseyre P, Allienne JF, Girerd-Chambaz Y, Guillou $F$, Bouchut A, Coustau C: Gene discovery and expression analysis of immune-relevant genes from Biomphalaria glabrata hemocytes. Dev Comp Immunol 2005, 29:393-407.

6. Lockyer AE, Spinks JN, Walker AJ, Kane RA, Noble LR, Rollinson D, Dias-Neto E, Jones CS: Biomphalaria glabrata transcriptome: Identification of cell-signalling, transcriptional control and immune-related genes from open reading frame expressed sequence tags (ORESTES). Dev Comp Immunol 2007, 3 I :763-782.

7. Hanelt B, Lun CM, Adema CM: Comparative ORESTES-sampling of transcriptomes of immune-challenged Biomphalaria glabrata snails. J Invertebr Pathol 2008 in press.

8. Raghavan N, Knight $M$ : The snail (Biomphalaria glabrata) genome project. Trends Parasitol 2006, 22: I48-I5I.

9. Dejong RJ, Emery AM, Adema CM: The mitochondrial genome of Biomphalaria glabrata (Gastropoda : Basommatophora), intermediate host of Schistosoma mansoni. J Parasitol 2004, 90:991-997.

10. Adema CM, Luo MZ, Hanelt B, Hertel LA, Marshall J, Zhang SM, Dejong RJ, Kim HR, Kudrna D, Wing RA, et al.: A bacterial artificial chromosome library for Biomphalaria glabrata, intermediate snail host of Schistosoma mansoni. Mem Inst Oswaldo Cruz 2006, I01:167-177.

II. Lockyer AE, Jones CS, Noble LR, Rollinson D: Trematodes and snails: an intimate association. Can J Zool 2004, 82:25I-269.

12. Knaap WPW van der, Loker ES: Immune mechanisms in trematode-snail interactions. Parasitol Today 1990, 6:175-182.

13. Adema CM, Loker ES: Specificity and immunobiology of larval digenean snail associations. In Advances in Trematode Biology Edited by: Fried B, Graczyk TK. Florida: CRC Press; 1997:230-253.

14. Loker ES, Adema CM, Zhang SM, Kepler TB: Invertebrate immune systems - not homogeneous, not simple, not well understood. Immunological Reviews 2004, I98: 10-24.

15. Zhang SM, Adema CM, Kepler TB, Loker ES: Diversification of Ig superfamily genes in an invertebrate. Science 2004, 305:25I-254.

16. Bayne CJ, Hahn UK, Bender RC: Mechanisms of molluscan host resistance and of parasite strategies for survival. Parasitology 200I, I 23:SI59-167.

17. Bayne CJ: Origins and evolutionary relationships between the innate and adaptive arms of immune systems. Integr Comp Biol 2003, 43:293-299.

18. Goodall CP, Bender RC, Brooks JK, Bayne C): Biomphalaria glabrata cytosolic copper/zinc superoxide dismutase (SODI) gene: Association of SODI alleles with resistance/susceptibility to Schistosoma mansoni. Mol Biochem Parasitol 2006, | 47:207-210.

19. Bender RC, Goodall CP, Blouin MS, Bayne CJ: Variation in expression of Biomphalaria glabrata SODI: A potential controlling factor in susceptibility/resistance to Schistosoma mansoni. Dev Comp Immunol 2007, 3 I :874-878.

20. Lockyer AE, Jones CS, Noble LR, Rollinson D: Use of differential display to detect changes in gene expression in the intermediate snail host Biomphalaria glabrata upon infection with Schistosoma mansoni. Parasitology 2000, I 20:399-407.

21. Lockyer AE, Noble LR, Rollinson D, Jones CS: Schistosoma mansoni : resistant specific infection-induced gene expression in Biomphalaria glabrata identified by fluorescent-based differential display. Exp Parasitol 2004, 107:97-104. 
22. Jones CS, Lockyer AE, Rollinson D, Noble LR: Molecular approaches in the study of Biomphalaria glabrata - Schistosoma mansoni interactions: linkage analysis and gene expression profiling. Parasitology 200I, I 23:SI8I-196.

23. Schneider O, Zelck UE: Differential display analysis of hemocytes from schistosome- resistant and schistosome-susceptible intermediate hosts. Parasitol Res 200I, 87:489-49I.

24. Raghavan N, Miller AN, Gardner M, FitzGerald PC, Kerlavage AR, Johnston DA, Lewis FA, Knight M: Comparative gene analysis of Biomphalaria glabrata hemocytes pre- and post-exposure to miracidia of Schistosoma mansoni. Mol Biochem Parasitol 2003 , 126:181-191.

25. Miller AN, Raghavan N, FitzGerald PC, Lewis FA, Knight M: Differential gene expression in haemocytes of the snail BiomphaIaria glabrata : effects of Schistosoma mansoni infection. Int Parasitol 200I, 3 I :687-696.

26. Nowak TS, Woodards AC, Jung YH, Adema CM, Loker ES: Identification of transcripts generated during the response of resistant Biomphalaria glabrata to Schistosoma mansoni infection using suppression subtractive hybridization. J Parasitol 2004, 90:1034-1040.

27. Lockyer AE, Spinks J, Noble LR, Rollinson D, Jones CS: Identification of genes involved in interactions between Biomphalaria glabrata and Schistosoma mansoni by suppression subtractive hybridization. Mol Biochem Parasitol 2007, I 5 I : I 8-27.

28. Loker ES, Bayne C], Buckley PM, Kruse KT: Ultrastructure of encapsulation of Schistosoma mansoni mother sporocysts by hemocytes of juveniles of the 10-R2 strain of Biomphalaria glabrata. J Parasitol 1982, 68:84-94.

29. Petalidis L, Bhattacharyya S, Morris GA, Collins VP, Freeman TC, Lyons PA: Global amplification of mRNA by template-switching PCR: linearity and application to microarray analysis. Nucleic Acids Res 2003, 3 I:.

30. Subkhankulova T, Livesey Fj: Comparative evaluation of linear and exponential amplification techniques for expression profiling at the single-cell level. Genome Biology 2006, 7:

31. Cao Y, Zhao H, Hollemann T, Chen YL, Grunz H: Tissue-specific expression of an ornithine decarboxylase paralogue, XODC2, in Xenopus laevis. Mech Dev 200I, 102:243-246.

32. Rom E, Kahana C: Isolation and characterization of the Dro sophila ornithine decarboxylase locus - Evidence for the presence of 2 transcribed ODC genes in the Drosophila genome. DNA Cell Biol 1993, I 2:499-508.

33. Damian RT: Parasite immune evasion and exploitation: reflections and projections. Parasitology 1997, II 5:SI69-SI75.

34. Thomas T, Thomas TJ: Polyamines in cell growth and cell death: molecular mechanisms and therapeutic applications. Cell $\mathrm{Mol}$ Life Sci 200I, 58:244-258.

35. Rhee HJ, Kim EJ, Lee JK: Physiological polyamines: simple primordial stress molecules. I Cell Mol Med 2007, I I :685-703.

36. Ha HC, Sirisoma NS, Kuppusamy P, Zweier JL, Woster PM, Casero RA: The natural polyamine spermine functions directly as a free radical scavenger. Proc Natl Acad Sci USA 1998 95: I I|40- II|45.

37. Ha HC, Yager JD, Woster PA, Casero RA: Structural specificity of polyamines and polyamine analogues in the protection of DNA from strand breaks induced by reactive oxygen species. Biochem Biophys Res Commun 1998, 244:298-303.

38. Adema CM, van deutekom Mulder EC, Knaap WPW van der, Sminia $\mathrm{T}$ : Schistosomicidal activities of Lymnaea stagnalis hemocytes - the role of oxygen radicals. Parasitology 1994, 109:479-485.

39. Hahn UK, Bender RC, Bayne C): Involvement of nitric oxide in killing of Schistosoma mansoni sporocysts by hemocytes from resistant Biomphalaria glabrata. J Parasitol 200I, 87:778-785.

40. Albina JE, Caldwell MD, Henry WL, Mills CD: Regulation of macrophage functions by L-arginine. J Exp Med 1989, 169:1021-1029.

41. Witte MB, Barbul A: Arginine physiology and its implication for wound healing. Wound Repair Regen 2003, I I:419-423.

42. Shearer JD, Richards JR, Mills CD, Caldwell MD: Differential regulation of macrophage arginine metabolism: A proposed role in wound healing. Am J Physiol 1997, 272(2 Pt I):EI8I-EI90.

43. Curran JN, Winter DC, Bouchier-Hayes D: Biological fate and clinical implications of arginine metabolism in tissue healing. Wound Repair Regen 2006, | 4:376-386.
44. Brunet LR: Nitric oxide in parasitic infections. International Immunopharmacology 200 I, I: |457-I467.

45. Hahn UK, Bender RC, Bayne CJ: Killing of Schistosoma mansoni sporocysts by hemocytes from resistant Biomphalaria glabrata: Role of reactive oxygen species. J Parasitol 2001, 87:292-299.

46. Tirard CT, Grossfeld RM, Levine JF, Kennedy-Stroskopf S: Effect of hyperthermia in vitro on stress protein synthesis and accumulation in oyster hemocytes. Fish Shellfish Immunol 1995, 5:9-25.

47. Lacoste A, De Cian MC, Cueff A, Poulet SA: Noradrenaline and alpha-adrenergic signaling induce the hsp70 gene promoter in mollusc immune cells. J Cell Sci 200 I, I | 4:3557-3564.

48. Lange S, Xiang FQ, Yakovenko A, Vihola A, Hackman P, Rostkova E, Kristensen J, Brandmeier B, Franzen G, Hedberg B, et al.: The kinase domain of titin controls muscle gene expression and protein turnover. Science 2005, 308: | 599-|603.

49. Vibert P, Edelstein SM, Castellani L, Elliott BW: Mini-titins in striated and smooth molluscan muscles - structure, location and immunological cross-reactivity. J Muscle Res Cell Motil 1993. | 4:598-607.

50. Funabara D, Kanoh S, Siegman MJ, Butler TM, Hartshorne DJ, Watabe $\mathrm{S}$ : Twitchin as a regulator of catch contraction in molluscan smooth muscle. J Muscle Res Cell Motil 2005, 26:455-460.

51. Helfand BT, Chang L, Goldman RD: Intermediate filaments are dynamic and motile elements of cellular architecture. J Cell Sci 2004, I I 7: |33-|4|.

52. Bouchut A, Sautiere PE, Coustau C, Mitta G: Compatibility in the Biomphalaria glabrata/Echinostoma caproni model: Potential involvement of proteins from hemocytes revealed by a proteomic approach. Acta Trop 2006, 98:234-246.

53. Adjaye J, Plessmann U, Weber K, Dodemont $\mathrm{H}$ : Characterization of neurofilament protein NF70 mRNA from the gastropod Helix aspersa reveals that neuronal and nonneuronal intermediate filament proteins of cerebral ganglia arise from separate lamin-related genes. J Cell Sci 1995, I08:358I-3590.

54. Helfand BT, Chou YH, Shumaker DK, Goldman RD: Intermediate filament proteins participate in signal transduction. Trends Cell Biol 2005, I 5:568-570.

55. Lorenzen JA, Baker SE, Denhez F, Melnick MB, Brower DL, Perkins LA: Nuclear import of activated D-ERK by DIM-7, an importin family member encoded by the gene moleskin. Development 200I, I28:|403-|4|4.

56. Zahoor Z, Davies AJ, Kirk RS, Rollinson D, Walker AJ: Disruption of ERK signalling in Biomphalaria glabrata defence cells by Schistosoma mansoni: Implications for parasite survival in the snail host. Dev Comp Immunol 2008 in press.

57. Creutz CE, Tomsig JL, Snyder SL, Gautier MC, Skouri F, Beisson J, Cohen J: The copines, a novel class of $C 2$ domain-containing, calcium-dependent, phospholipid-binding proteins conserved from Paramecium to humans. I Biol Chem 1998 273: $1393-1402$

58. Tomsig JL, Sohma H, Creutz CE: Calcium-dependent regulation of tumour necrosis factor-alpha receptor signalling by copine. Biochem J 2004, 378:1089-1094.

59. Ramsey CS, Yeung F, Stoddard PB, Li D, Creutz CE, Mayo MW: Copine-I represses NF-kappa B transcription by endoproteolysis of p65. Oncogene 2008, 27:35 I6-3526.

60. Jambunathan N, McNellis TW: Regulation of Arabidopsis COPINE I gene expression in response to pathogens and abiotic stimuli. Plant Physiol 2003, I32:|370-I38|

61. Myers J, Ittiprasert W, Raghavan N, Miller A, Knight M: Differences in cysteine protease activity in Schistosoma mansoni -resistant and -susceptible Biomphalaria glabrata and characterization of the hepatopancreas Cathepsin B full-length cDNA. Parasitol 2008:659-668.

62. Knop M, Schiffer HH, Rupp S, Wolf DH: Vacuolar/lysosomal proteolysis: proteases, substrates, mechanisms. Curr Opin Cell Biol 1993, 5:990-996.

63. Turk B, Turk D, Turk V: Lysosomal cysteine proteases: more than scavengers. Biochim Biophys Acta 2000, I477( I-2):98- I I I

64. Zavasnik-Bergant T, Turk B: Cysteine cathepsins in the immune response. Tissue Antigens 2006, 67:349-355.

65. Loseva $O$, Engstrom Y: Analysis of signal-dependent changes in the proteome of Drosophila blood cells during an immune response. Molecular \& Cellular Proteomics 2004, 3:796-808. 
66. Irving $P$, Troxler L, Heuer TS, Belvin M, Kopczynski C, Reichhart JM, Hoffmann JA, Hetru C: A genome-wide analysis of immune responses in Drosophila. Proc Natl Acad Sci USA 200I, 98:15119-15124.

67. Zhao ZY, Yin ZX, Weng SP, Guan HJ, Li SD, Xing K, Chan SM, He JG: Profiling of differentially expressed genes in hepatopancreas of white spot syndrome virus-resistant shrimp (Litopenaeus vannamei) by suppression subtractive hybridisation. Fish Shellfish Immunol 2007, 22:520-534.

68. Bouchut A, Coustau C, Gourbal B, Mitta G: Compatibility in the Biomphalaria glabrata/Echinostoma caproni model: new candidate genes evidenced by a suppressive subtractive hybridization approach. Parasitology 2007, 134:575-588.

69. Guillou F, Roger E, Mone Y, Rognon A, Grunau C, Threron A, Mitta G, Coustau C, Gourbal BEF: Excretory-secretory proteome of larval Schistosoma mansoni and Echinostoma caproni, two parasites of Biomphalaria glabrata. Mol Biochem Parasitol 2007, I55:45-56.

70. Hershko A, Ciechanover A: The ubiquitin system. Annu Rev Biochem 1998, 67:425-479.

7I. Altschul SF, Gish W, Miller W, Myers EW, Lipman DJ: Basic Local Alignment Search Tool. J Mol Biol 1990, 215:403-4I0.

72. Lockyer AE, Noble LR, Rollinson D, Jones CS: Isolation and characterization of the full-length CDNA encoding a member of a novel cytochrome p450 family (CYP320AI) from the tropical freshwater snail, Biomphalaria glabrata, intermediate host for Schistosoma mansoni. Mem Inst Oswaldo Cruz 2005, 100:259-262.

73. Paraense WL, Correa LR: Variation in susceptibility of populations of Austrolorbis glabratus to a strain of Schistosoma mansoni. Rev Inst Med Trop Sao Paulo 1963, 5: I 5-22.

74. Cleveland WS: Lowess - a program for smoothing scatterplots by robust locally weighted regression. American Statistician 1981, 35:54-54.

75. Muller PY, Janovjak H, Miserez AR, Dobbie Z: Processing of gene expression data generated by quantitative real-time RTPCR. Biotechniques 2002, 32:1372-1379.

76. Pfaffl MW: A new mathematical model for relative quantification in real-time RT-PCR. Nucleic Acids Res 200I, 29:.

Publish with Bio Med Central and every scientist can read your work free of charge

"BioMed Central will be the most significant development for disseminating the results of biomedical research in our lifetime. "

Sir Paul Nurse, Cancer Research UK

Your research papers will be:

- available free of charge to the entire biomedical community

- peer reviewed and published immediately upon acceptance

- cited in PubMed and archived on PubMed Central

- yours - you keep the copyright
BioMedcentral 